\title{
ESTIMULAÇÃO ELÉTRICA TRANSCUTÂNEA (TENS) COMO TERAPIA DE SUPORTE DAS MIALGIAS MASTIGATÓRIAS
}

Andressa MARENDA; Lilian CUSTÓDIO

Estimulação elétrica transcutânea (TENS) é uma modalidade terapêutica que promove analgesia, através da emissão de estímulos elétricos à pele por meio de eletrodos posicionados nas áreas dolorosas ou próximas a elas. A transmissão desses estímulos gera a estimulação das fibras de grande diâmetro induzindo a inibição das fibras de pequeno diâmetro dos tipos A-delta e $C$ que são responsáveis pela condução dos estímulos nociceptivos. $O$ aparelho possui dois tipos de freqüência: a alta - que atua em nível sensorial, ativando o sistema de portão modulador da dor no nível da medula espinhal, e a baixa, atuando a nível motor, através da liberação de beta-endorfinas. É indicada para controlar a dor crônica, dor pós-cirúrgica, assim como reduzir a dor aguda pós-traumática, mas está contra-indicada no caso de dor de origem central ou idiopática. Quando utilizada no tratamento das DTM, deve ser entendida como uma medida de suporte, atuando no controle álgico e disfuncional. O presente trabalho tem como objetivo, através de uma revisão da literatura, apresentar o TENS como uma modalidade coadjuvante de tratamento das mialgias mastigatórias. 